Volume 8, No.1.5, 2019

International Journal of Advanced Trends in Computer Science and Engineering

Available Online at http://www.warse.org/IJATCSE/static/pdf/file/ijatcse4281.52019.pdf

https://doi.org/10.30534/ijatcse/2019/4281.52019

\title{
Online Consumer Behavior on Using Social Media on E-Commerce, based on the AISAS Model Approach. Case Study; Bukalapak, Tokopedia and Blili.com
}

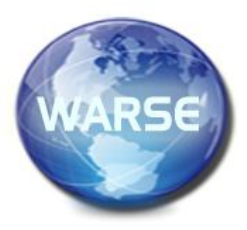

\section{ABSTRACT}

The development of the technology industry also enhances online marketing strategies. It shapes consumer behavior. To measure consumer behavior online, the AISAS model can be used. This model was developed to measure online consumers in the marketplace Bukalapak, Tokopedia and Blibli.com. This study used 100 online consumer respondents as a sample, from the amount that cannot be identified. Data collected by online questionnaires. This research tested by quantitative methods with SEM-PLS analysis. The results of hypothesis testing indicate that 3 of 8 hypotheses were rejected. Relationship of attention to interests, interest in search, search for actions, actions towards shares and the search for positive and significant sharing. Whereas the relationship of attention to actions, interest in actions, and attention to shares don't affect positively and significantly. Further research also needs to consider other variables that can influence online consumer behavior, such as gender control, education level, age, income level, etc. These research model enriches the concept of consumer behavior in marketing, especially in online media. These results indicate that consumers in their behavior on social media, especially online media, have special characteristics. This paper contributes scholars by examining the AISAS model and how it relates to online consumer behavior

Key words : AISAS, Online Consumer Behavior, E-Commerce, Social Media Marketing

\section{INTRODUCTION}

The fast advancement of innovation expects us to proceed to adjust and see each open door that exists. Mechanical advances affect all enterprises [1]. Current item promoting should in addition to the fact that possible be through electronic media, print media and direct selling, however at this point web-based life is additionally one of the item advertising devices that are broadly utilized by businessmen.

In general, based on the APJII survey report 2019, discusses the increase in internet users in Indonesia, increasing by around $8 \%$ to 143.26 million. This is equivalent to $54.68 \%$ of
Indonesia's population of more than 262 million people. The surge in internet users in Indonesia discusses new patterns of interaction in society, namely through social media. Accessing social media is one of the activities most often carried out by Indonesian people to access the internet. The results of a survey conducted on 2,500 samples and randomly selected showed $87.13 \%$ of internet users access social media when using the internet [2]. A large number of social media users make social media an increasing channel for sending unlimited messages to audiences and extensions. Social media is now present as a market that can easily influence people in it.

Web innovation has turned into achievement in different parts of the life of Indonesian individuals. This innovation enables Indonesian individuals to get to data and associate rapidly, effectively and efficiently through the idea of on the web. In a moderately brief time, the quantity of web clients in Indonesia has expanded altogether. In view of information from the Centre for Communication Studies and the Internet Service Providers Association (2018), it demonstrated that there was a huge increment in the number of web clients in Indonesia.

Social expansion media makes an altogether new period for organizations and brand improvement, innovation likewise underpins them to discover better approaches to encourage and encourage their clients [3] [4]. This quickly growing promoting channel, which has achieved multiple thirds of all Web clients, gives unrivalled chances to fabricate marks and contend [5] [6]. Albeit web-based life gives new chances and advantages to marking the executives [7], one of the provokes that keeps on developing is the trouble in estimating the inspiration of web-based life showcasing on the extent of brands [8] [9].

New business like web-based shopping destinations truly contributes to promoting correspondence through web-based life since online networking have two ground-breaking advantage, minimal effort, and high effect. Further examined demonstrated that the enormous errand for web-based shopping destinations organization is to make an advertising correspondence's technique in a powerful and proficient approach to impact customers eagerness to purchase in internet shopping locales. Something else that ought not to be 
overlooked is the procedure of buyer choices making. The basic leadership process with AIDA display (Awareness, Interest, Desire, and Action) is by all accounts obsolete and should be supplanted with AISAS (Attention, Interest, Search, Action, Share) show. This implies, shoppers in this time is shown have considerably more entangled conduct.

Customers who are keen on one item, won't promptly settling on a choice to purchase, however through an extra stage first, which is hunting down extra data about the item by means of web to be their thought. Outfitted with the information of AISAS show, web-based shopping destinations ought to define messages that can build mindfulness, invigorate intrigue, and having great execution in online survey so shopper will go the following phase of the AISAS demonstrate, that is purchase the item and record their shopping background as review.

This study holds several accounts from three online shopping sites in Indonesia. The three online shopping sites that are the object of research are Bukalapak, Tokopedia dan Blibli.com. The three online shopping sites were chosen because they are considered as the most popular online shopping sites in Indonesia based on the ranking on Alexa.com. The Alexa.com rating in April 2019 shows that Bukalapak is the number 1 most visited site in Indonesia compared to similar sites. After Bukalapak, Tokopedia reached second place on the most visited site in Indonesia for the same category and blibli.com in third place.

This examination means to produce a finding to comprehend AISAS models towards Marketing Communications in Social Media on Online shopping locales, whereby the AISAS model would be inspected at each phase to create a thorough comprehension of the relationship between's each measurement and factors of AISAS models.

\section{LITERATURE REVIEW}

\subsection{AISAS}

When customers need goods with high involvement, customers will conduct a deeper search than goods with low involvement. Therefore, a marketing communication model derived from technological developments, which is named the AISAS model [10]. When compared this model to AIDA, it will be seen that the process of psychological transformation which are Action, Interest, Desire and Memory has been simplified into Action and Interest only. At that point the last one for the action procedure has been extended to incorporate Search to Action and Action to Share. So the model progresses toward becoming Attention to Interest, Interest to Search, Search to Action, and Action to Share.

\subsection{Social Media in Marketing}

The advertising interchanges medium has advanced from print media, electronic media, and afterward to web-based life on the internet. Clients in the new thousand years are changing excitement to online shopping, yet also to find information through electronic life before settling on purchase decisions. This example exhibits that customers will as a rule trust their partners and contacts in electronic long range informal communication over the advancements appeared by business affiliations [11]. Online life has realized significant changes to the systems and instruments used by business relationship to talk with customers. Online life instruments consolidate the highlights of customary incorporated advertising specialized devices (business associations speak with the clients) with verbal showcasing (customers talk with one another) in which advancing bosses can't control the substance of certain information [12]. Association in online life is considered all the more appealing exchange where information can be shown in various structures, for instance, the sharing of experiences, jokes, recording, and comments from companions. Social events for sharing information and experiences can shape purchaser impression of the thing or organization offered by business affiliations. The information can be passed on quickly and along these lines influence thing execution and stamping [11].

Web-based life mechanical assemblies can be used by business relationship of various sizes and types as a promoting gadget [13]. Electronic life engages business relationship to interface with customers at the perfect time, really with lower cost and higher efficiency than other standard specific mechanical assemblies. This grants electronic long range interpersonal communication not only to be cornered by broad business affiliations, yet notwithstanding the little and medium endeavors [7]. Likewise, web-based life areas, for instance, Facebook and Twitter empower customers to seek after their most adored brands and to comment or post tends to related to related things or organizations. With online life goals, business affiliations can recognize what is being said about their brands and examine direct with buyers [14]. Customers can help business relationship to make new business and to progress or help any brand through tweeting, blogging, assessing, following, and so forth. Customers who are reliable to a particular brand in like manner help produce electronic displaying through a virtual verbal publicizing methodology, which is indispensable for business. Associations with shoppers offer business the chance to utilize web-based life as a device for their showcasing methodologies14. In any case, numerous private ventures are as yet endeavoring to achieve their intended interest group successfully [15] and many areas yet ignorant of the possibilities of online networking advertising. Social media marketing is a process that empowers individuals and companies to promote their websites, products or services online and through social channels to communicate with a much larger community that is not possible through traditional advertising channels [16].

Online life gives amazing opportunities to accomplish clients in their informal organizations and amass progressively near 
their affiliations [17]. Electronic life has changed the way where brand substance is made, passed on, and exhausted, trading the capacity to shape brand pictures from publicists to purchasers' online affiliations and substance [18]. Web-based life affiliation is basically changing correspondence among brands and customers [3] [7] [19] find that social collaboration is a basic assistant for making client produced content. Online life can offer clients help similarly as space for talks and the exchanging of musings. As demonstrated social affiliation portrays customers who add to check related electronic life arranges in order to meet comparative others, interface, and chat with them about unequivocal things/brands [20].

\subsection{Marketing Communication Integration}

Marketing communication is a means by companies that try to inform, persuade, and remind consumers (directly or indirectly) about the products and brands they sell. In a sense, marketing communication is the voice of the company and brand. By strengthening customer loyalty, marketing communication can contribute to customer equity [21].

Web advertising is the most grounded approach to construct brands and begin and reinforce associations with clients. In any case, online advertisers must be more brilliant to plan and convey brand messages that catch and keep up client consideration. Characterize coordinated promoting correspondence as a cross-practical procedure for arranging, actualizing, and checking showcasing interchanges intended for the benefit of procuring, keeping up, and developing clients [22]. Incorporated advertising correspondence is cross-useful in light of the fact that each touch point the client has with the organization or specialist shapes the brand picture.

\section{RESEARCH FRAMEWORK}

Consumer awareness of a product becomes something that must be considered by marketers to increase consumer intentions in making purchasing decisions. The higher the level of potential consumers' attention to a new product, the higher the intention of the prospective consumer to make a purchase decision [10] [13] [28] [29] [30] [31]. Based on this and the explanation in the introduction above, the following hypothesis can be formulated;

H1: Attention has a positive and significant relationship to Interest.

Information retrieval of a product occurs when a potential customer is interested in the product. This interest will increase information search activities both online and offline. In the AISAS model, the search for information referred to is through online media. The higher the interest of potential customers in a product, the higher the activity of consumers to search for information [10] [32] [31] [34]. Based on this and the explanation in the introduction above, the following hypothesis can be formulated;

$\mathrm{H} 2$ : Interest has a positive and significant relationship to
Search.

Adequacy of information obtained by consumers will facilitate consumers in making purchasing decisions. Obtaining sufficient information about a product, raises the high intensity of decision making by online consumers. The higher the intensity of information retrieval carried out by consumers, the higher the level of decision making [10] [32] [33] [34]. Based on this and the explanation in the previous introduction, a hypothesis can be formulated as follows;

H3: Search has a positive and significant relationship to Action.

Purchase decisions made by consumers will provide experience and new knowledge for consumers in assessing a product. Consumer ratings of a product can be positive or negative. the higher the intensity of purchasing decisions by consumers the more information they get will also be disseminated online [10] [35] [36] [37]. Based on this and the explanation that has been presented in the introduction above, then the next hypothesis can be formulated in this study as follows;

H4: Action has a positive and significant relationship to Share.

Promotions conducted by online marketers in general are aimed at introducing their products to the wider community. The introduction of products in general also aims to get the attention of consumers so that consumers can make purchasing decisions. The higher the consumer's attention, the higher the purchasing decisions that might be made by consumers [23] [24] [26] [43]. Based on this and the previous preliminary explanation above, the following hypotheses in this study can be formulated;

H5: Attention has a positive and significant relationship to Action.

Purchasing decisions made by consumers are based on interest in a particular product. The higher the level of consumer interest in a product, the higher the purchase decision intentions will be made by consumers in the purchase process [27] [43] [44]. Based on this study and the previous discussion, the following hypotheses in this study can be formulated;

H6: Interest has a positive and significant relationship to Action.

Share information on a product can be preceded by a search for information in advance by consumers. The higher the intention to search for information by consumers, the higher the intention of consumers to share information they get [10] [40] [41] [42]. Based on the explanation in the previous introduction and the results of previous studies, the following hypotheses in this study can be formulated;

H7: Search has a positive and significant relationship to Share. 
Consumer attention to a product raises a variety of responses, one of which is to share information they get to other people online. The higher the consumer's attention to the product, the higher the intention to share the information they get [10] [43] [45]. Based on this study and the discussion in the introduction above, the hypotheses in this research can be formulated as follows;

H8: Attention has a positive and significant relationship to Share.

By considering all the explanations for the theories discussed above, discussing the positive and negative aspects that exist in these theories, a research model is developed that can describe the conditions of consumer behavior in online shopping in 3 marketplaces namely Bukalapak, Tokopedia and Blibli.com. In this study there are 8 hypotheses, all of these hypotheses are made based on the results of modifications or development of the systematics of the AISAS model. The thinking framework of this study is as follows:

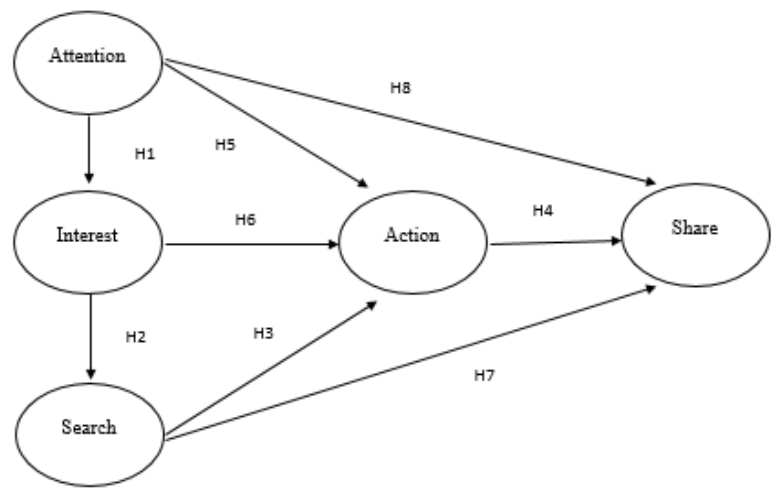

Figure 1: Research Framework

The theory above depends on the connection between the factors created by the exploration which produced the AISAS model itself [10]. In the framework of this research also see how the direct effect of Intention on Action, Interest on Action, and Search on Share, which is the basic model of AISAS is not explained before.

\section{RESEARCH METHODOLOGY}

The population used in this study were all consumers of Bukalapak, Tokopedia, and Blibli.com whose numbers could not be identified. The sampling technique in this study was purposive random sampling with a total sample of 100 people. This purposive sampling technique is a technique that determines the sample based on certain criteria and determined intentionally by the researcher [33]. Criteria for determining the sample in this study include; minimal high school education, individuals who purchase and use Bukalapak, Tokopedia and blibli.com are doing the most recent three months of research and have at least two social media accounts from Facebook, Twitter, or Instagram. The survey was conducted in April, 1st to April, 30th 2019.
The measurement scale used in this study is the Likert scale, which is a scale that has been widely used to ask respondents to mark the degree of approval or disagreement with a series of stimulus objects. The Likert scale used is 1 to strongly disagree to 5 strongly agree.

Data analysis in this study used the Partial Least Square (PLS) approach. PLS is an equation model for Structural Equation Modelling (SEM) based on components or variants. To commend the theory and produce a practical model, this investigation utilizes SEM with fluctuation based or segment-based methodology with (PLS). On the off chance that the structural model to be analysed meets the recursive model and the latent variable has normative indicators. Reflective or mixed, the most proper way to deal with use is PLS.

\section{RESULT}

\subsection{Instrument Reliability Test}

Reliability test aims to find out to what extent the consistency of the measuring instrument used so that when the measuring instrument is used again to examine the same object with the same technique even though the time is different than the results to be obtained are the same. To test the reliability level using Cronbach's coefficient efficient alpha indicates how far the items in the study are positively correlated with each other. Reliability refers to the value of cronbach's alpha with a cut off $\geq 0.60$ [25]. The results of this test can be seen from Table 1 bellow:

Table 1: Reliability Test Results

\begin{tabular}{|r|l|c|l|}
\hline \multirow{2}{*}{ No } & \multicolumn{1}{|c|}{ Variabel } & $\begin{array}{c}\text { Cronbach } \\
\text { Alpha }\end{array}$ & Results \\
\hline 1 & Share $(\mathrm{Y})$ & 0.897 & Reliabel \\
\hline 2 & Attention $(\mathrm{X} 1)$ & 0.894 & Reliabel \\
\hline 3 & Interest $(\mathrm{X} 2)$ & 0.894 & Reliabel \\
\hline 4 & Search $(\mathrm{X} 3)$ & 0.939 & Reliabel \\
\hline 5 & Action $(\mathrm{X} 4)$ & 0.932 & Reliabel \\
\hline
\end{tabular}

In assessing the outer model three criteria's are utilized, in particular, focalized legitimacy, discriminant legitimacy, and composite unwavering quality. Assessment of estimation models dependent on external stacking for intelligent pointers with criteria, in particular, intelligent criteria are viewed as substantial in the event that they have a stacking an incentive above 0.50 as well as a t-measurable incentive above 1.96 which implies that the model has united legitimacy.

The results of the attention, interest, search, action, and share research indicators have an outer loading value of more than 0.5 . The ambiguity indicator of the role is the strongest measure of the action variable because it has the highest outer loading value with a value of 0.936 . Because all indicators have an outer loading value of more than 0.5 , it can be concluded that these three indicators are valid indicators to measure the variable share. 
I Komang Sumerta et al., International Journal of Advanced Trends in Computer Science and Engineering, 8(1.5), 2019, 234 - 242

Assessment of the estimation model dependent on cross loading is utilized to evaluate whether the construct has great discriminant legitimacy. Discriminant legitimacy is viewed as legitimate on the if it has cross loading, every indicator in the pertinent variable has the biggest value compared with different cross loading latent factors. The consequences of cross loading of the three factors are exhibited in Table 3.

Table 3: Value of Cross Loading Research Model

\begin{tabular}{|l|l|l|l|l|l|}
\hline & $\begin{array}{l}\text { Actio } \\
\mathrm{n}\end{array}$ & $\begin{array}{l}\text { Attentio } \\
\mathrm{n}\end{array}$ & Interest & Search & Share \\
\hline $\mathrm{X} 1.1$ & 0.559 & $\mathbf{0 . 8 2 4}$ & 0.450 & 0.535 & 0.600 \\
\hline $\mathrm{X} 1.2$ & 0.480 & $\mathbf{0 . 8 9 9}$ & 0.621 & 0.512 & 0.514 \\
\hline $\mathrm{X} 1.3$ & 0.519 & $\mathbf{0 . 7 3 6}$ & 0.622 & 0.566 & 0.547 \\
\hline $\mathrm{X} 1.4$ & 0.474 & $\mathbf{0 . 8 6 5}$ & 0.674 & 0.555 & 0.523 \\
\hline $\mathrm{X} 1.5$ & 0.492 & $\mathbf{0 . 8 6 3}$ & 0.504 & 0.513 & 0.544 \\
\hline $\mathrm{X} 2.1$ & 0.586 & 0.542 & $\mathbf{0 . 7 3 6}$ & 0.595 & 0.632 \\
\hline $\mathrm{X} 2.2$ & 0.452 & 0.532 & $\mathbf{0 . 8 4 5}$ & 0.515 & 0.469 \\
\hline $\mathrm{X} 2.3$ & 0.512 & 0.641 & $\mathbf{0 . 8 5 5}$ & 0.586 & 0.555 \\
\hline $\mathrm{X} 2.4$ & 0.413 & 0.500 & $\mathbf{0 . 8 5 1}$ & 0.449 & 0.443 \\
\hline $\mathrm{X} 2.5$ & 0.514 & 0.645 & $\mathbf{0 . 9 0 0}$ & 0.576 & 0.557 \\
\hline $\mathrm{X} 3.1$ & 0.729 & 0.619 & 0.615 & $\mathbf{0 . 9 0 9}$ & 0.762 \\
\hline $\mathrm{X} 3.2$ & 0.627 & 0.574 & 0.580 & $\mathbf{0 . 9 0 7}$ & 0.662 \\
\hline $\mathrm{X} 3.3$ & 0.679 & 0.561 & 0.596 & $\mathbf{0 . 8 5 3}$ & 0.718 \\
\hline $\mathrm{X} 3.4$ & 0.677 & 0.536 & 0.574 & $\mathbf{0 . 9 0 5}$ & 0.726 \\
\hline $\mathrm{X} 3.5$ & 0.686 & 0.582 & 0.570 & $\mathbf{0 . 9 0 4}$ & 0.705 \\
\hline $\mathrm{X} 4.1$ & $\mathbf{0 . 8 1 8}$ & 0.465 & 0.518 & 0.622 & 0.812 \\
\hline $\mathrm{X} 4.2$ & $\mathbf{0 . 8 7 3}$ & 0.576 & 0.526 & 0.680 & 0.883 \\
\hline $\mathrm{X} 4.3$ & $\mathbf{0 . 9 3 6}$ & 0.573 & 0.549 & 0.699 & 0.824 \\
\hline $\mathrm{X} 4.4$ & $\mathbf{0 . 9 0 6}$ & 0.477 & 0.452 & 0.668 & 0.848 \\
\hline $\mathrm{X} 4.5$ & $\mathbf{0 . 9 0 2}$ & 0.581 & 0.607 & 0.700 & 0.809 \\
\hline $\mathrm{Y} 1.1$ & 0.676 & 0.639 & 0.628 & 0.721 & $\mathbf{0 . 8 1 8}$ \\
\hline $\mathrm{Y} 1.2$ & 0.818 & 0.465 & 0.518 & 0.622 & $\mathbf{0 . 8 1 2}$ \\
\hline $\mathrm{Y} 1.3$ & 0.873 & 0.576 & 0.526 & 0.680 & $\mathbf{0 . 8 8 3}$ \\
\hline $\mathrm{Y} 1.4$ & 0.778 & 0.552 & 0.526 & 0.631 & $\mathbf{0 . 8 5 7}$ \\
\hline $\mathrm{Y} 1.5$ & 0.805 & 0.521 & 0.513 & 0.715 & $\mathbf{0 . 8 3 6}$ \\
\hline & & & & & \\
\hline
\end{tabular}

In view of the table 3 above it very well may be seen that the cross loading acquired by each latent variable is higher than the other latent factors with the goal that it tends to be said that the latent variable has satisfied discriminant legitimacy.

The construct reliability of the estimation model with reflective indicators can be estimated by taking at the reliability composite value and fortified by the Cronbach's alpha value. The reliability quality composite and Cronbach's alpha qualities are great in the event that they have an estimation of $\geq 0.70$ [25]. Coming up next are the result of the instrument reliability concentrates exhibited in Table 4.
Table 4: Composite Reliability Research Model

\begin{tabular}{|l|l|c|c|l|}
\hline No & Variables & $\begin{array}{l}\text { Composite } \\
\text { Reliability }\end{array}$ & $\begin{array}{l}\text { Cronbachs } \\
\text { Alpha }\end{array}$ & Results \\
\hline 1 & Action (X4) & 0.949 & 0.932 & Reliable \\
\hline 2 & Attention (X1) & 0.922 & 0.894 & Reliable \\
\hline 3 & Interest (X2) & 0.922 & 0.894 & Reliable \\
\hline 4 & Search (X3) & 0.953 & 0.939 & Reliable \\
\hline 5 & Share (Y) & 0.924 & 0.897 & Reliable \\
\hline
\end{tabular}

In view of Table 4 above demonstrates that the composite reliability value and the Cronbach's alpha value for all constructs have an estimation of more than 0.7. In this way in the examination model, each exploration build satisfies great reliability.

Testing the inner model or structural model aims to see the relationship between latent constructs, significance values and $\mathrm{R}$-square of the determined research model. Based on the research model that has been determined and has been tested by SEM-PLS analysis, the results of testing the inner model are as follows in Figure 2.

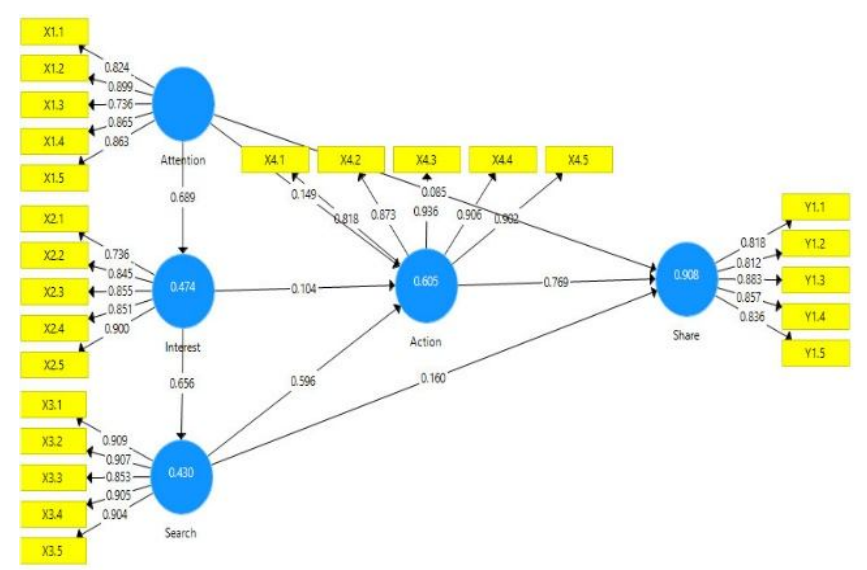

Figure 2: The result of structural model analysis

The R-square in this study was used to measure the construct of the dependent variables, while the parameters of each variable were tested using the $t$ test and also saw the significance values of each parameter. This is done to evaluate the model of structural path parameters.

Table 5: R-square

\begin{tabular}{|l|c|}
\hline \multicolumn{1}{|c|}{ Variables } & R-square \\
\hline Action & 0.605 \\
\hline Interest & 0.474 \\
\hline Search & 0.430 \\
\hline Share & 0.908 \\
\hline
\end{tabular}

Table 5 can be seen if the R-square value of the action variable is 0.605 . This can be interpreted that $60.5 \%$ of the variability of the action construct is explained by the variables of attention, interest, search, and share, while $39.5 \%$ of the action variables are explained by variables outside the model. Interest variables have R-square $47.4 \%$ of variability explained by attention, action, search, and share while $52.6 \%$ of interest variables are explained by variables outside the 
model. The search variable has a R-square of $43 \%$ of the variability explained by attention, action, interest, and share while $57 \%$ of the search variables are explained by variables outside the model. Then the variable R-square share of $90.8 \%$ of its variability explained attention, action, interest, and search while $9.2 \%$ was explained by variables outside the model.

\subsection{Hypothesis Testing}

The value of each parameter seen from its significance value shows information related to the relationship between the variables used in this study. Testing the hypothesis in this study is to use or refer to the output path coefficients values as shown in table 6 below.

Table 6: Path Coefficients

\begin{tabular}{|l|c|c|c|c|}
\hline \multicolumn{1}{|c|}{ Variables } & $\begin{array}{c}\text { Path } \\
\text { Coefficient } \\
\boldsymbol{s}\end{array}$ & $\begin{array}{c}\boldsymbol{t} \\
\text { statistic } \\
\boldsymbol{s}\end{array}$ & $\begin{array}{c}\text { P - } \\
\text { Valu } \\
\mathbf{e}\end{array}$ & Result \\
\hline $\begin{array}{l}\text { Action (X4) -> } \\
\text { Share (Y) }\end{array}$ & 0.769 & 15.630 & 0.000 & $\begin{array}{c}\text { Accepte } \\
\mathrm{d}\end{array}$ \\
\hline $\begin{array}{l}\text { Attention (X1) } \\
->\text { Action (X4) }\end{array}$ & 0.149 & 1.543 & 0.123 & Rejected \\
\hline $\begin{array}{l}\text { Attention (X1) } \\
\text {-> Interest } \\
\text { (X2) }\end{array}$ & 0.689 & 12.244 & 0.000 & $\begin{array}{c}\text { Accepte } \\
\mathrm{d}\end{array}$ \\
\hline $\begin{array}{l}\text { Attention (X1) } \\
->\text { Share (Y) }\end{array}$ & 0.085 & 1.782 & 0.075 & Rejected \\
\hline $\begin{array}{l}\text { Interest (X2) } \\
->\text { Action (X4) }\end{array}$ & 0.104 & 1.125 & 0.261 & Rejected \\
\hline $\begin{array}{l}\text { Interest }(\mathrm{X} 2) \\
->\text { Search } \\
\text { (X3) }\end{array}$ & 0.656 & 10.765 & 0.000 & $\begin{array}{c}\text { Accepte } \\
\mathrm{d}\end{array}$ \\
\hline $\begin{array}{l}\text { Search (X3) } \\
\text {-> Action (X4) }\end{array}$ & 0.596 & 6.349 & 0.000 & $\begin{array}{c}\text { Accepte } \\
\mathrm{d}\end{array}$ \\
\hline $\begin{array}{l}\text { Search (X3) } \\
\text {-> Share (Y) }\end{array}$ & 0.160 & 3.227 & 0.001 & $\begin{array}{c}\text { Accepte } \\
\mathrm{d}\end{array}$ \\
\hline
\end{tabular}

Hypothesis testing can be done in two ways, testing using $\mathrm{t}$-statistics and $\mathrm{p}$-value. For t-statistic test, if the value of $\mathrm{t}$-statistics $\geq \mathrm{t}$-table value (1.98), then the research hypothesis is accepted. Based on table 6 above, 3 of the 8 constructs have a t-statistics value smaller than t-table, namely attention to action constructs of 1.543 , attention to share constructs of 1.782 , and interest in action 1.125 .

Testing the statistical relationship of variables can also be seen from the value of the coefficients path for each variable relationship showing a positive and significant relationship because the p-value is less than 0.0525 . With this test it can also be seen that there are 3 constructs that are rejected among others; attention to action with p-value 0.123 , attention to share with p-value 0.075 and interest construct to action with a p-value of 0.261 .

Based on the hypothesis test above, it can be concluded that the hypotheses $\mathrm{H} 5, \mathrm{H} 6$, and $\mathrm{H} 8$ are rejected while the hypotheses $\mathrm{H} 1, \mathrm{H} 2, \mathrm{H} 3, \mathrm{H} 4$, and $\mathrm{H} 7$ are accepted.

\section{DISCUSSION}

Hypothesis test results show that attention has a positive and significant effect on the interest of people to make online purchases in the Bukalapak, Tokopedia and Blibli.com marketplace. This result means that the more someone is aware of the existence of the promotion carried out by Bukalapak, Tokopedia and Blibli.com it will increase the interest of that person to make purchases in the marketplace. This is supported by studies such as those conducted by previous research who obtained results similarly, attention has a positive and significant effect on interest [10] [28] [29] [30] [31] [13].

Based on the hypothesis test found that interest has a positive and significant effect on search. This means that the more someone is attracted to the promotion carried out by the Bukalapak / Tokopedia / Blibli.com marketplace, it will also increase the search intention of the prospective customers. The search can be in the form of searching for information through information sources online and offline. This is consistent with research conducted by previous research find that interest has a positive and significant effect on search [10] [32] [33] [34].

Based on the hypothesis test found that search has a positive and significant effect on action. This means that the more someone is attracted to find the information of the Bukalapak / Tokopedia / Blibli.com marketplace, it will also increase the action of the customer to make a decision. The search can be in the form of searching for information through information sources online and offline. This is consistent with research conducted by previous research find that Search has a positive and significant effect on Action [10] [32] [33] [34].

Based on the hypothesis test found that action does not have a significant effect on the share. This means that, actions taken by consumers do not make consumers spread the information they get. This is in accordance with previous studies that action does not have a significant effect on the share [35] [36] [37].

Based on the hypothesis test found that attention does not have a significant effect on the action. This means that the attention obtained by consumers from the promotions carried out by Bukalapak, Tokopedia and Blibli.com does not have an influence on the actions of consumers from the marketplace. Based on the search through the statement of the distributed questionnaire, this can occur because the promotion content carried out by Bukalapak, Tokopedia and Blibli.com is less attractive so it is not able to direct consumers to take further action. The results of this hypothesis testing are supported by previous research, who found that attention does not have a significant effect on action [33].

Based on the hypothesis test found that interest does not have a significant effect on the action. This means that consumer interest gained from promotions made by Bukalapak, Tokopedia and Blibli.com does not have an effect on the actions of consumers in the marketplace. Based on the search 
through the statement of the distributed questionnaire, this can occur because the limited information by the promotional content carried out by Bukalapak, Tokopedia and Blibli.com is less attractive so it is not able to direct consumers to take further action. The results of this hypothesis testing are supported by previous research who found that interest did not have a significant effect on action [38] [39].

Based on the hypothesis test found that search has a positive and significant effect on share. This means that the information sought by consumers from promotions carried out by Bukalapak, Tokopedia and Blibli.com has an influence on the dissemination of information through consumers' social media from the marketplace's promotional content. The results of this hypothesis testing are supported by research by previous research who found that search has a positive and significant effect on share [10] [40] [41] [42].

Based on the hypothesis test found that attention does not have a significant effect on share. This means that the attention obtained by consumers from the promotions carried out by Bukalapak, Tokopedia and Blibli.com does not have an effect on the dissemination of information through consumers' social media from the marketplace's promotional content. The results of this hypothesis testing are supported by previous research found that attention did not have a significant effect on share [33] [43] [48] [49].

\section{CONCLUSION}

Based on the findings in this study, it can be concluded that this research model enriches the concept of consumer behavior in marketing, especially in online media. The results of this study indicate that consumers in their behavior in social media, especially online media, have special characteristics. Consumers can go through the stages of behavior that are generally carried out, and or even cannot go through these stages sequentially but can directly enter the stages that are needed. In the AISAS model, the stages of the consumer in behaving in the online media have been arranged in such a way as to design that the consumer will be aware of the existence of a product (Attention), from that awareness will emerge an interest. After consumers feel interested, a greater curiosity will emerge, the curiosity can be realized through online information search. Information seeking will lead to action that can be a purchase decision (Action) in the form of a positive action by deciding to buy the product or negative action that decides not to buy the product. The next action will be to send consumers to disseminate information (Share) and / or their experiences from the beginning of the process until the decision is taken [10].

In this study, it was found that consumer behavior is very flexible. These things can be seen from the Attention variable having a positive effect on Action, the Interest variable has a positive effect on Action and attention to share variables, although the three relationships proved in this study not to have a significant effect, other relationships that are Search for Share in this study have positive and significant. It is expected that the results of this study can be used as reference material in knowing the development of online product marketing strategies that specifically use social media as a means of promotion and development of consumer behavior, especially online consumers of the products offered.

The scope of this research is only for consumers of Bukalapak, Tokopedia and Blibli.com products, so that the results of the study cannot be generalized to consumers of online products in general. Further research also needs to consider other variables that can influence the behavior of online consumers, such as gender control, education level, age, income level and so on.

\section{REFERENCES}

1. Akinci, S., Aksoy, S., dan Atilgan, E. Adoption of internet banking amongsophisticated consumer segments in an advanced developing country. The International Journal of Bank Marketing, Vol. 22, No. 3, hal. 212-232. 2004.

https://doi.org/10.1108/02652320410530322

2. Asosiasi Penyelenggara Jasa Internet Indonesia [APJII]. Indonesian Internet User Profile. Jakarta: Asosiasi Penyelenggara Jasa Internet Indonesia. 2018.

3. Gallaugher, J. and Ransbotham, S. Social media and customer dialog management at Starbucks, MIS Quarterly Executive, Vol. 9, No.4, pp. 197-212. 2010.

4. Kozinets, Robert, V., Kristine de Valck., Sarah J.S. Wilner and Andrea Wojniki. Networked Narratives: Understanding Word of Mouth Marketing in Online Communities. Journal of Marketing Vol. 74. 2010.

https://doi.org/10.1509/jm.74.2.71

5. Correa, J. E. Nutritive Value of Goat Meat. Alabama A\&M University. Alabama Cooperative Extension System. 2011.

6. Perrey and Spillecke. Retail Marketing and Branding. UK : Wiley: A John Wiley and Sons ,Ltd Publication. 2011. https://doi.org/10.1002/9781119207900

7. Kaplan, A.M., and Haenlein, M. Users of the world, unite! The challenges and opportunities of Social Media. Business Horizons, 53, 59-68. 2010.

8. Schultz, Friederike, Utz, Sonja and Göritz, Anja. Is the Medium the Message? Perceptions of and Reactions to Crisis Communication via Twitter, Blogs and Traditional Media. Public Relations Review, 37(1): 20-27. 2011.

9. Schultz, D., and Peltier, J. Social Media's Slippery Slope: Challenges, Opportunities and Future Research Directions. Journal of Research, 7(2), 86-99. 2013.

10. Sugiyama, K., Andree, T., and The Dentsu Cross Switch Team. The Dentsu Way. NewYork: McGraw-Hill. 2010.

11. Woodcock, N., Green, A and Starkey, M. Social CRM as a Business Strategy. Journal of Management, 18(1), 50-64. 2011. https://doi.org/10.1057/dbm.2011.7 
12. Mangold, WG. and Faulds, DJ. Social Media: The New Hybrid Element of The Promotion Mix. Business Horizons. 2009.

13. Birkner, C.. Lifestyle Brands Make It PERSONAL. Marketing News, 45, (2), 22. 2011.

14. Reyneke, M.,Pitt,L.,Berthon,P.R.,.Luxury wine brand visibility in social media: an exploratory study. Int $\mathrm{J}$ Wine Bus Res.23,21-35. 2011.

15. Braci, E., and Vagnoni, E. Understanding Small Family Business Succession in aKnowledge Management Perspective. The IUP Journal of Knowledge Management, 9(1), 7-36. 2011.

16. Drury, Glen. Social Media: "Should Marketers Engage and How Can it be Done Effectively". Journal of Direct, Data and Digital Marketing Practice. (9). 274277. 2008.

17. Kelly, L., Kerr, G., and Drennan, J.. "Avoidance of Advertising in Social Networking. Journal of Interactive Advertising, Vol 10 No 2(Spring 2010), pp. $16 \square 272010$.

https://doi.org/10.1080/15252019.2010.10722167

18. Men, L,R., and Tsai, W,S. Infusing Social Media with Humanity: Corporate Character, Public, Engagement, and Relational Outcomes. Journal of Public Relation. 2015. https://doi.org/10.1016/j.pubrev.2015.02.005

19. Daugherty, T., Eastin, M. S., and Bright, L. Exploring Consumer Motivations For Creating User Generated content. Journal of Interactive Advertising, 8(2). 2008.

20. Muntinga, D. G., Moorman, M., and Smit, E. G. Introducing COBRAs: Exploring motivationsfor brand-related social media use. International Journal of Advertising, 30(1), 13-46. 2011.

21. Kotler, Philip and Keller, Kevin Lane. Marketing Management, Volume 1, Issue 13, Erlangga. 2013

22. Strauss and Frost. E-Marketing, Sixth Edition, Pearson: New Jersey. 2011.

23. Yu, T., Guo, C., Wang, L., Gu, H., Xiang, S., and Pan, C. Joint Spatial-Temporal Attention For Action Recognition. Pattern Recognition Letters, 112, 226-233. 2018.

https://doi.org/10.1016/j.patrec.2018.07.034

24. Ghafur, R. D., Suri, G., and Gross, J. J. Emotion Regulation Choice: The Role of Orienting Attention And Action Readiness. Current Opinion in Behavioral Sciences, 19, 31-35. 2018.

25. Hair, J.F., Anderson, R.E., Tatham, R.L. and Black W.C. Multivariate Data Analysis 4th Edition. New Jersey: Prentice-Hall. 2010.

26. Shepherd, D. A., Mcmullen, J. S., and Ocasio, W. Is That An Opportunity? An Attention Model Of Top Managers' Opportunity Beliefs For Strategic Action. Strategic Management Journal, 38(3), 626-644. 2016. https://doi.org/10.1002/smj.2499

27. Pan, Y., Yang, K., Hong, Z. and Lin, H. The Effect Of Interest And Engagement In Learning Science On Adults' Scientific Competency And Environmental Action. Eurasia Journal of Mathematics, Science and Technology Education, 14(12), 1-12. 2018.
28. Hoek, J. and Gendall, P. How Does Sponsorship Work. In the proceeding of the ANZMAC. 1-3 December, 2003, Adelaide, pp. 9 16. Sites: The Teenager Perspective." Journal of Interacting Advertising, 10(2), 16-27. 2003.

29. Ardian Bahri and Rayza. Analysis of the Effect of Endorsers on Social Media on Product Purchasing Decision Making Using the AISAS Method. Tesis. Universitas Indonesia. 2012.

30. Kirtis, A.K. and Karahan, F. To Be Or Not To Be In Social Media Arena As The Most Cost Efficient Marketing Strategy After The Global Recession. In the Proceding of Social and Behaviorial Sciences, pp. 260-268, 7th International Strategic Management Conference. 2011. https://doi.org/10.1016/j.sbspro.2011.09.083

31. Chen G-X. Based On The AISAS Model Under The Perspective Of Publishing Enterprise Micro Blogging Marketing. J Hunan Norm Univ J Soc Sci 12:154- 160. 2014.

32. Lagrosen, S. Effects Of The Internet On The Marketing Communication Of Service To Companies. Journal of Services Marketing. 19(2), 63-69. 2005.

33. Fifa Italia dan Henry F. Noor. AISAS Model Analysis towards MarketingCommunication in Social Media on Online Shopping Sites: Case study of Lazada Indonesia, Mataharimall and Tokopedia. IGCC Proceeding. Universitas Indonesia. 2017.

34. Kim, SE., Lee KY., Shin SI, Yang SB. Effects of tourism information quality in social media on destination image formation: The case of Sina Weibo. Information and Management. doi: 10.1016/j.im.2017.02.009. 2017.

35. Power, D. J. and Phillips-Wren, G. Impact of Social Media and Web 2.0 on Decision Making. Journal of Decision Systems. doi: 10.3166/jds.20.249-261.S. P. Bingulac. On the compatibility of adaptive controllers, in Proc. 4th Annu. Allerton Conf. Circuits and Systems Theory, New York, 1994, pp. 8-16. 2011.

36. Lin, Tom M.Y, Lu, Kuan-Yi, and Wu, Jia-Jhou. The effects of visual information in eWOM communication. Journal of Research in Interactive Marketing, Vol. 6 Issue: 1, pp. 7-26. 2012.

37. Cheung, Christy M.K. and Thadani, Dimple R.. The Effectiveness of Electronic Word of Mouth Communication: A Literature Analysis. BLED 2010 Proceedings, Vol 18. 2010.

38. Syahid Abdurrahim, Muhamad. Development of AISAS Model To See The Effect OfTourism Destination In Social Media Jam. Journal of Applied Management (JAM). Vol 17. No 1. 2019.

39. Wei, W., Miao, L., and Huang, Z (Joy). Customer Engagement Behaviors and HotelResponses. International Journal of Hospitality Management, 33, 316-330. 2013.

40. Samira, S. Globe Asia: Surprising Bagels. Retrieved from:http://www.thejakartaglobe.com/entrepreneurs/sur prising-bagels/482296. 2011. 
41. Meyerson, M. Success Secrets of the Social Media Marketing Superstars. Canada: Library of Congress Cataloging-in-Publication Data. 2010.

42. Morris, MR., Counts S., A Roseway., A Hoff. Tweeting is Believing Understanding Microblog Credibility PerceptionsMeredith. Proc. CSCW 2012. doi: $10.1145 /$ 2145204.2145274. 2012.

43. Hendriyani, Jessica Jane, Lenny Ceng, Nabilah Utami, Reinata Priskila, Stefania Anggita. Online Consumer Behavior: Confirming the AISAS Model on Twitter Users. International Conference on Social and Political Sciences (ICSPS). 2013.

44. Yadav, G. K., Shukla, P., and Sethfi, A. Action recognition using interest points capturing differential motion information. 2016 IEEE International Conference on Acoustics, Speech and Signal Processing (ICASSP). 2016.

45. Lee, J., Kim, S., and Ham, C.-D. A Double-Edged Sword? Predicting Consumers' Attitudes Toward and Sharing Intention of Native Advertising on Social Media. American Behavioral Scientist, 60(12), 1425-1441. 2016.

46. Vishal Goyal., Pandey., U.S. Sanjay Batra. Mobile Banking in India: Practices, Challenges and Security Issues. International Journal of Advanced Trends in Computer Science and Engineering, 1(2), May - June 2012, 56 - 66. 2012.

47. Sonal Rajurkar., Urvashi Kodwani., Ankita Singh., and Shyamal Mundada. Online Prescription for Skin Diseases. International Journal of Advanced Trends in Computer Science and Engineering, 8(2), March - April 2019, $176-181.2019$. https://doi.org/10.30534/ijatcse/2019/11822019

48. T. Hariguna, \& Berlilana, "Understanding of Antecedents to Achieve Customer Trust and Customer Intention to Purchase E-Commerce in Social Media, an Empirical Assessment", International Journal of Electrical and Computer Engineering, 7(3), 1240-1245, 2017. http://doi.org/10.11591/ijece.v7i3.pp1240-1245

49. U. Rahardja, T. Hariguna, \& Q. Aini, "Understanding the Impact of Determinants in Game Learning Acceptance: An Empirical Study", International Journal of Education and Practice, 7(3), 136-145, 2019. http://doi.org/10.18488/journal.61.2019.73.136.145 